\title{
Typhonium flagelliforme decreases telomerase expression in HeLa cervical cancer cells
}

\author{
Endang Purwaningsih*, Yulia Suciati**, and Etty Widayanti*
}

\begin{abstract}
\section{BACKGROUND}

Cancer cells have a relatively high telomerase activity compared to normal cells, so that cancer cells have the ability for continued proliferation and uncontrolled mitosis. Telomerase is an enzyme responsible for the length of telomeres, DNA segments located at the ends of eukaryotic chromosomes. Natural materials such as rodent tuber (Typhonium flagelliforme) have anticancer potential. The purpose of the present study was to determine the effects of Typhonium flagelliforme extract on telomerase expression in HeLa cervical cancer and T47D breast cancer cells.
\end{abstract}

\section{METHODS}

This experimental laboratory study was conducted on cultured HeLa and T47D cancer cell lines, with normal Vero cells as controls, and using RPMI and M199 culture media. The study comprised three groups, i.e. controls, and groups receiving Typhonium flagelliforme extract at doses of $1 / 2$ IC50 and IC50. Telomerase expression was measured by immunohistochemistry (IHC). Analysis of variance and LSD multiple comparison test were used to analyze the data.

\section{RESULTS}

Telomerase expression in cancer cells showed significantly higher values compared to normal Vero cells. Typhonium flagelliforme extract was capable of significantly decreasing telomerase expression in cancer cells receiving the extract.

\section{CONCLUSION}

Typhonium flagelliforme extract at different doses is capable of decreasing telomerase expression more effectively in cervical cancer cells than in breast cancer cells. This study shows that Typhonium flagelliforme may have anti-cancer activity, necessitating further investigations.

Keywords: Telomerase, IHC, Typhonium flagelliforme, HeLa and T47D cancer cells

\author{
*Department of Anatomy, \\ Faculty of Medicine, \\ YARSI University, Jakarta \\ **Department of Biochemistry, \\ Faculty of Medicine, \\ YARSI University, Jakarta
}

\section{Correspondence}

Prof. Dr. Endang Purwaningsih, MS, PA

Department of Anatomy,

Faculty of Medicine,

YARSI University,

Jl. Letjend. Suprapto

Cempaka Putih, Jakarta 10510

Phone: +6221-4206674/76

Email: endpurwaning@gmail.com

Univ Med 2015;35:3-9

DOI: 10.18051/UnivMed.2016.v35.3-9 pISSN: 1907-3062 / eISSN: 2407-2230

This open access article is distributed under a Creative Commons Attribution-Non Commercial-Share Alike 4.0 International License 


\section{INTRODUCTION}

The use of traditional medications or natural substances is at present steadily increasing. Although modern therapeutics has advanced considerably, it is relatively expensive and may cause major adverse effects, particularly in the treatment of cancers, while its active compounds are not or less selective in killing cancer cells. In addition, the management of tumors or cancers has many constraints, since tumors or cancers are insensitive to antiproliferative signals and are capable of avoiding apoptosis. ${ }^{(1,2)}$ One type of therapy that is attracting attention is chemotherapy using bioactive substances obtained by synthesis or isolation of natural materials, one of these being the rodent tuber (Typhonium flagelliforme Lodd.). ${ }^{(3,4)}$ The DNA segments located at both ends of the chromosomes, known as telomeres, are one of the factors associated with the development of cancers. Telomere length is maintained by the telomerase enzyme. The actual shape of this enzyme may differ from species to species, but each of these versions have an RNAspecific template for the formation of new telomere subunits. Telomerase activity in normal cells is mainly found in reproductive cells (germline cells), since these have unlimited proliferative capacity. ${ }^{(5)}$

Indonesia is known as one of the countries with the greatest biological diversity, so that it has the potential for developmental efforts in medicine to produce drugs that are derived from medicinal plants. These plants produce secondary metabolites of the alkaloid, terpenoid and flavonoid categories with anticancer activities. One of the plants containing compounds with potential anticancer activity is rodent tuber (Typhonium flagelliforme Lodd.), ${ }^{(6)}$ which also may counteract the adverse effects of chemotherapy.

Several previous studies using cultured T4 lymphoblastoid and WEHI-3 leukemia cells have reported that Typhonium flagelliforme may inhibit cancer cell proliferation and induce apoptosis. ${ }^{(7-9)}$ According to a study conducted in Malaysia, rodent tuber may decrease pain, metastases or dissemination of cancer cells, comprising mammary, nasopharyngeal, cervical, prostatic, pancreatic, and pulmonary cancers. ${ }^{(7)}$ In addition, rodent tuber grows abundantly in Indonesia and Malaysia, and has been used for the treatment of hemorrhoids and skin diseases, for neutralizing narcotic drugs, and has antibacterial and antioxidant properties. ${ }^{(8,9)}$

Regarding the chemical compounds of rodent tuber, there is a scarcity of information. Phytochemical analyses of rodent tuber performed at the Research Station for Medicinal and Aromatic Plants (Balai Penelitian Tanaman Obat dan Aromatik) showed the presence of alkaloids, saponins, steroids, and glycosides, but the specific active substances in rodent tuber that play a role in the healing of cancers are as yet unknown. ${ }^{(10)}$ The saline extract of Typhonium flagelliforme contains ribosome inactivating proteins (RIPs), which are proteins with the ability to cut cancer cell DNA or RNA, so that they inactivate cancer cell development without damage to the surrounding tissues. In addition, RIPs can also block cancer cell growth. ${ }^{(10,11)}$

Typhonium flagelliforme extract contains antineoplastic or anticancer compounds. ${ }^{(12)}$ It has also been reported that Typhonium flagelliforme extract at a dose of $200 \mathrm{mg} / \mathrm{kgBW}$ may decrease protein kinase and Ki67 protein expression in rats. ${ }^{(13)}$ Furthermore, Typhonium flagelliforme extract may have antiproliferative properties and significantly induce apoptosis of NCI-H23 pulmonary cancer cells and nontumoral BALB/ c3T3 rat fibroblasts. ${ }^{(14,15)}$

Since rodent tuber has anticancer potential and cancer cells in general show high telomerase expression, we wished to determine the potency of Typhonium flagelliforme extract on telomerase expression. No information is available on the effect of Typhonium flagelliforme extract on telomerase expression in T47D breast cancer and HeLa cervical cancer cells. Typhonium flagelliforme extract has cytotoxic effects, with differing IC 50 doses in 
different cancer cell types. The purpose of this study was to evaluate telomerase expression in cultured HeLa and T47D cancer cells after administration of Typhonium flagelliforme extract.

\section{METHODS}

\section{Study design}

This was an experimental laboratory study conducted at the Parasitology Laboratory, Faculty of Medicine, Gadjah Mada University from April until November 2013. The study used one control group (of normal Vero cells) and two experimental groups (of HeLa and T47D cancer cells, respectively), where each cancer cell group received three doses (control dose, $1 / 2$ IC50 and 1 IC50).

\section{Study subjects}

The study subjects were cultured T47D breast cancer, HeLa cervical cancer and normal Vero cell lines, obtained from the Parasitology Laboratory, Faculty of Medicine, Gadjah Mada University. The cells were cultured in 24-well microplates using Rosswell Park Memorial Institute (RPMI) medium, with two replications per group. The cultures were incubated for 72 hours or until the cultures became confluent, at a density of $1 \times 10^{4}$ cells per well. After confluence, the cultures were treated with their previously determined doses of Typhonium flagelliforme extract.

\section{Plant materials}

Rodent tuber plants were obtained from medicinal herb gardens in the Jagakarsa area in South Jakarta.

\section{Preparation of cell culture and cell growth media}

The cell culture media for HeLa and T47D cells were prepared by dissolving one sachet each of RPMI and M199 powders, respectively, in around $800 \mathrm{~mL}$ twice-distilled water, with the addition of 2.0 gram sodium bicarbonate and 2.0 gram HEPES, and adding twice-distilled water to obtain a volume of one liter. The solutions were mixed with a magnetic stirrer for around 10 minutes until homogenous, then neutralized with $1 \mathrm{~N} \mathrm{HCl}$ to a $\mathrm{pH}$ of $7.2-7.4$. The cell growth medium was prepared by mixing $19 \mathrm{~mL}$ fetal bovine serum (FBS), $2 \mathrm{~mL}$ penicillinstreptomycin, and $0.5 \mathrm{~mL}$ fungizone, then diluting with the respective culture media to a volume of $100 \mathrm{~mL}$. Subsequently the solutions were aseptically filtered using sterile $0.2 \mu \mathrm{m}$ polyethylene sulfone filters. The filtered solutions were stored in the refrigerator in stoppered bottles.

\section{Preparation of Typhonium flagelliforme extract}

Typhonium flagelliforme whole plant extract was prepared as follows: all fresh and cleansed plant parts were cut into thin strips and air-dried. Then the strips were blenderized into a powder. The powder was macerated in $80 \%$ ethanol in an Erlenmeyer flask, under continued shaking. Subsequently the ethanolic extract was poured into a rotary flask and concentrated using a rotary evaporator. The rodent tuber concentrate was dissolved in dimethyl silfoxide (DMSO), diluted into several concentrations, and filtered through $0.2 \mu \mathrm{m}$ filters before being placed on the 24-well plates. From the preliminary cytotoxicity assay of the Typhonium flagelliforme extract on the three cell lines (Vero, T47D and HeLa cells) were obtained the respective IC50 values of $60.50 \mu \mathrm{g} / \mathrm{ml}, 66.90$ $\mu \mathrm{g} / \mathrm{mL}$, and $30.198 \mu \mathrm{g} / \mathrm{ml}$. The interventions were performed after the cell cultures attained a concentration of $5 \times 10^{4}$ cells per well.

\section{Immunohistochemical telomerase expression assay}

The HeLa, T47D, and Vero cell cultures at a density of $10^{4}$ cells per well, that were attached to coverslips, were immunohistochemically stained at the Parasitology Laboratory, Faculty of Medicine, Gadjah Mada University, using the following procedure. The cell cultures on 
coverslips that had been given interventions, were incubated in a $5 \% \mathrm{CO}_{2}$ incubator at $37^{\circ} \mathrm{C}$ for 24 hours, and were then removed and placed on poly-L-lysine slides, and fixed with acetone or methanol for 10 minutes at $-20^{\circ} \mathrm{C}$. The slides were then washed in phosphate-buffered solution (PBS) for $3 \times 5$ minutes ( 3 times for 5 minutes each), and $0.3 \% \mathrm{H}_{2} \mathrm{O}_{2}$ was dripped onto the slides for 20 minutes. The slides were dripped with normal mouse serum (1:50) for 15 minutes, and the liquid was discarded without washing. Then the slides were dripped with primary (telomerase) antibody for 60 minutes. After washing in PBS for $3 \times 5$ minutes, the slides were incubated in biotinylated secondary antibody for 5-10 minutes, and washed in PBS for $3 \times 5$ minutes. After incubation in streptavidin-peroxidase for 5-10 minutes and washing in PBS for $3 \times 5$ minutes, the slides were incubated in the chromogen diaminobenzidine tetrahydrochloride (DAB) for 5-10 minutes, at a ratio of chromogen to substrate of 1:20, then washed in distilled water. The slides were then immersed in hematoxylin for 3-5 minutes for counterstaining, washed in distilled water and dehydrated using $95 \%$ ethanol followed by xylene, each for 10 minutes. Subsequently the slides were given a drop of mounting medium (Canada balsam) and covered with a coverslip. Telomerase expression was observed using the light microscope. Cells with telomerase expression are brown in color, whereas cells without telomerase expression are bluish purple in color. Observation of telomerase expression by the IHC method is performed by counting the number of expression-positive (brown-colored) cells among 100 cells examined. The results are expressed as percentages.

\section{Data analysis}

Data were analyzed using the Anova test, followed by the least significant difference (LSD) multiple comparison test using SPSS version 18.

\section{RESULTS}

The telomerase test results for each cancer cell type after administration of Typhonium flagelliforme extract in the form of the percentages of telomerase expression-positive cells in all three cell groups at their respective doses are presented in Table 1.

Telomerase expression was significantly higher in T47D breast cancer and HeLa cervical cancer cells than in normal Vero cells. Administration of Typhonium flagelliforme extract showed decreased telomerase expression at doses both of one-half and one HeLa cell IC50 and at doses of one-half and one T47D cell IC50 (Table 1).

According to the results of the multiple comparison test with LSD on telomerase expression, there were significant differences between the groups (data not shown). Administration of Typhonium flagelliforme extract was capable of decreasing telomerase expression in both cancer cell types, both at doses of $1 / 2$ IC50 and of 1 IC50. Typhonium flagelliforme extract at a dose of $1 / 2$ IC50 and 1 IC50 was capable of producing a highly significant decrease in telomerase expression $(p<0.01)$ in HeLa cells. On the other hand, in T47D cells, a far greater dose was of $1 / 2$ IC50 and 1 IC50 required, to be able to cause a highly significant reduction in telomerase expression $(\mathrm{p}<0.001)$.

Table 1. Mean telomerase expression of each type of cancer cells by experimental group

\begin{tabular}{lcccccccccc}
\hline & $\begin{array}{c}\text { Nonmal } \\
\text { Vero } \\
\text { controk }\end{array}$ & $\begin{array}{c}\text { Vero } \\
\text { 1/2ICS0 }\end{array}$ & $\begin{array}{c}\text { Vero } \\
\text { 1 IC50 }\end{array}$ & $\begin{array}{c}\text { TD47D } \\
\text { contros }\end{array}$ & $\begin{array}{c}\text { T47D } \\
\text { 1/2ICSD }\end{array}$ & $\begin{array}{c}\text { TD47D } \\
\text { 1 IC50 }\end{array}$ & $\begin{array}{c}\text { HeLa } \\
\text { controk }\end{array}$ & $\begin{array}{c}\text { HeLa } \\
1 / 2 \text { IC50 }\end{array}$ & $\begin{array}{c}\text { HeLa 1 } \\
\text { IC50 }\end{array}$ & p \\
\hline Telomerase & $3.67 \pm$ & $0.67 \pm$ & $0.00 \pm$ & $89.00 \pm$ & $31.00 \pm$ & $16.33 \pm$ & $81.67 \pm$ & $22.33 \pm$ & $11.00 \pm$ & 0.000 \\
expression & 1.16 & 0.57 & 0.00 & 2.65 & 4.00 & 5.77 & 7.23 & 0.58 & 2.65 & \\
$(\%)$ & & & & & & & & & & \\
\hline
\end{tabular}




\section{DISCUSSION}

Our study results showed that telomerase expression in both types of cancer cells was greater than in normal Vero cells. After administration of rodent tuber (Typhonium flagelliforme Lodd.) extract, telomerase expression in both cancer cell types showed decrease, and telomerase expression was lower in HeLa cells than in T47D cells. At a lower dose, telomerase expression in HeLa cells showed a greater decrease in expression in comparison with the dose of 1 IC50 in T47D cells. This shows that the compound in Typhonium flagelliforme extract was more effective or more potent as an anticancer agent in HeLa cells than in T47D cells. It has been reported that there are 4 active fractions contained in rodent tuber, i.e. pheophorbide-a, pheophorbide-a', pyropheophorbide-a and pyropheophorbide-a'. Other compounds that have been identified are oleic acid, linoleic acid, stigmasterol, and beta sitosterol. ${ }^{(15)}$ It is postulated that the active substances in Typhonium flagelliforme extract are more potent in decreasing telomerase expression in HeLa cells than in T47D cells. It is known that telomerase has an important role in the maintenance and stabilization of telomere length, which may affect cancer cell proliferation. ${ }^{(16)}$. In this case the active compounds in Typhonium flagelliforme extract are probably more effective in affecting telomere length of $\mathrm{HeLa}$ cells, so that the inhibition of proliferation of these cells is greater. However, this necessitates further studies.

In this connection, previous investigators have reported that cancer cells have differing resistance or sensitivity to different chemotherapeutic or antineoplastic compounds, and it is possible that telomerase plays a role in this case. Several tumor cell cultures show decreased telomerase activity after treatment with antineoplastic drugs. ${ }^{(17)}$ The use of rodent tuber (Typhonium flagelliforme Lodd.) as an anticancer agent has demonstrated that this plant has an anticancer effect against pulmonary cancer cells (NCI-H23 cells) by inhibiting their proliferation and stimulating their apoptosis. ${ }^{(14)}$ Dichloromethane and acetylacetic extracts of Typhonium flagelliforme Lodd. also have an anticancer effect against leukemia cells. It has been reported that administration of rodent tuber leaf extract (at doses of 19.8 and $5.8 \mu \mathrm{g} / \mathrm{mL}$ ) and rodent tuber rhizomes (at doses of 6.5 and 8.2 $\mu \mathrm{g} / \mathrm{mL}$ ) may be antiproliferative against CEMss leukemia cells. ${ }^{(8)}$

Telomerase is a ribonucleoprotein enzyme that serves to maintain the protective structures at the ends of eukaryotic chromosomes, called the telomeres. Telomerase is the structure responsible for the maintenance of the telomere, which consists of repeats of the nucleotides (TTAGGG)n. In most human somatic cells such as fibroblasts, telomerase expression is repressed and the telomere shortens progressively at each cell divison. On the other hand, the majority of human tumor or cancer cells express telomerase, so that the telomere length is stable. This observation shows that telomere maintenance is essential for tumor or cancer cell proliferation. This telomerase activity determines cell proliferation, both of cancer cells and normal cells in in-vitro and in-vivo conditions. ${ }^{(18)}$

In normal human cells such as fibroblasts, the aging process is not only determined by telomere length but also by hTERT (human telomerase reverse transcriptase) expression and telomerase activity. Abnormalities of telomerase activity in normal human cells slow down cell proliferation, limit the lifespan of the cells, and alter the maintenance of the single-strand telomeric overhang at the 3 ' end of the chromosome without altering the overall telomere shortening. Normal and cancer stem cells have different telomerase activities. ${ }^{(19,20)}$

In this study, in addition to the two cancer cell lines (HeLa and T47D), we also used normal Vero cells, which are somatic cells, namely fibroblasts. It is well-known that normal cells have a limited capacity for cell division, in general 40 to 50 generations, after which the cells stop dividing. Normal somatic cells, including stem cells, experience telomere shortening, that is 
meant for cell renewal. Therefore somatic cells have programmed aging and low telomerase expression. ${ }^{(21)}$

Previous studies on gastrointestinal (gastric and colonic) cancer cells have reported higher telomerase expression of the sub-units hTERT, hTR (human telomerase RNA), and telomeraseassociated protein 1 (TP1/TEP1) in these cells than in normal cells. Similarly, telomerase activity in the tested cancer cells was higher than in normal cells. Therefore telomerase may be a satisfactory marker for cancer incidence. ${ }^{(22)}$

Studies have been conducted by previous investigators on HeLa cells using triethylene tetraamine (TETA) by the modified telomeric repeat amplification (TRAP) method and flow cytometry. It is reported that triethylene tetraamine (TETA) in micromolar concentrations may inhibit proliferation of HeLa cells at the G1 phase. Telomerase activity in HeLa cells is considerable and the cells divide rapidly, in other words their proliferative level is high. This leads to the idea of telomerase inhibitors playing a role in the treatment of cancers through molecular mechanisms. ${ }^{(23)}$ Other studies reported that T47D cells also have high telomerase activity. Administration of curcumin and silibinin can inhibit the growth or proliferation of T47D cells and reduce the expression of the human telomerase reverse transcriptase (hTERT) gene. ${ }^{(24)}$ In addition, telomerase activity in pancreatic cancer cells is also high. Telomerase activity was determined in pancreatic cancer specimens as well as in metastatic lesions and was found to be higher in the metastatic lesions than in the primary tumor. Telomerase activity is low in non-malignant pancreatic lesions, such as benign adenomas, and acute and chronic lesions. ${ }^{(25)}$

This study had one limitation, in that it did not determine the effect of Typhonium flagelliforme extract on telomere length in $\mathrm{HeLa}$ and T47D cancer cells as compared with Vero cells. Further studies are necessary to determine the effect of Typhonium flagelliforme extract on telomere length in HeLa and T47D cells.

\section{CONCLUSIONS}

Administration of Typhonium flagelliforme extract is capable reducing telomerase expression, both in HeLa and T47D cells, although at differing doses. The reduction of telomerase expression in HeLa cells was more effective than that in T47D cells.

\section{CONFLICT OF INTEREST}

The investigators had no conflicting interests in this study.

\section{ACKNOWLEDGEMENTS}

The authors wish to express their gratitude to the Directorate General of Higher Education, who through the research fund for Decentralization of Outstanding Research in Higher Education, provided additional funding for the conduct of this study.

\section{REFERENCES}

1. Farida Y, Rahayu L, Faizatun. Aktivitas antioksidan Serbuk n-Heksana dan metanol hasil pengeringan semprot ekstrak keladi tikus (Typhonium flagelliforme L) Decne. Kongres Ilmiah XVIII Ikatan Apoteker Indonesia 2010;10 - 12 Desember 2010. Makasar;2010.

2. Putra A, Tjahjono, Winarto. Ekstrak keladi tikus (Typhonium flagelliforme) fraksi diklorometanolik dan ekspresi caspase-3 dan p21 cell line kanker payudara MCF-7. M Med Indones 2011;45:95-104.

3. Chadidjah, Nasihun T, Widayati E, et al. Typhonium flagelliforme decreases protein expression in murine breast cancer. Univ Med 2014;33:161-170.

4. Purwaningsih E, Widayanti E, Suciati Y. Cytotoxicity assay of Typhonium flagelliforme Lodd against breast and cervical cancer cells. Univ Med 2014;33:75-82.

5. Artandi SE, DePinho RA. Telomeres and telomerase in cancer. Carcinogenesis 2010;3:918.

6. Hariana HA. Tumbuhan Obat dan khasiatnya. Jakarta: Penerbit Swadaya: 2013. 
7. Mankaran S, Dinesh K, Deepak S, et al Typhonium falgelliforme: a multipurpose plant. Int Res J Pharm 2013;4:45-8.

8. Mohan S, Abdul AB, Wahab SIA, et al. Antibacterial and antioxidant activities of Typhonium flagelliforme (Lodd) Blume tuber. Am J Biochem Biotech 2008;4:402-7.

9. Mohan S, Abdul AB, Abdelwahab S, et al. Typhonium flagelliforme inhibits the proliferation of murine leukemia WEHI-3 cells in vitro and induced apoptosis in vivo. Leuk Res 2010;34:1483-92.

10. Syahid, Kristina NN. Induksi dan regenerasi kalus keladi tikus (Typhonium flagelliforme Lood) secara in vitro. Jurnal Littri 2007;13:1426.

11. de Virgilio M, Lombardi A, Caliandro R, et al. Ribosom in activating protein: from plant defense to tumor attack. Toxin 2010;2:2699-737.

12. Kainsa S, Kumar P, Rani P. Medicinal plants of Asian origin having anticancer potential: short review. Asian J Biomed Pharm Sci 2012;2:1-7.

13. Chadidjah, Dharmana E, Susanto $\mathrm{H}$, et al. Typhonium flagelliforme decreased tyrosine kinase and Ki67 expression in mice. Univ Med 2013;32:46-54.

14. Lai Cs, Mas RHM, Nair NK, et al. Typhonium flagelliforme inhibits cancer cell growth in vitro and induces apoptosis: an evaluation by the bioactivity guided approach. J Ethnopharmacol 2008;18:14-20.

15. Lai CS, Mas RH, Nair NK, et al. Chemical constituent and in vitro anticancer activity of Typhonium flagelliforme (Aracaceae). J Ethnopharmacol 2010;127:486-94.
16. Joseph I, Tressler R, Bassett E, et al. The telomerase inhibitor imetelstat depletes cancer stem cells in breast and pancreatic cancer cell lines. Cancer Res 2010;70:9494-504. DOI: 10.1158/0008-5472.CAN-10-0233.

17. Sakin V, Eskiocak U, Kars MD, et al. hTERT gene expression levels and telomerase activity in drug resistant MCF-7 cells. Exp Oncol 2008; 30:202-5.

18. Quellette MW, Wright WE, Shay JW. Targeting telomerase expressing cancer cells. J Cell Mol Med 2011;15:1433-42.

19. Masutomi K, Yu FY, Khurts S, et al. Telomerase maintans telomere structure in normal human cells. Cell 2003;114:241-53.

20. Shay JW, Wright WE. Telomeres and telomerase in normal and cancer stem cells. FEBS Letters 2010;584:3819-25.

21. Shay JW, Wright WE. Role of telomer and telomerase. Biology 2011;21:349-53.

22. Nowak J, Januszzkiewicz, Lewandowski K, et al. Activity and expression of human telomerase in normal and malignant cells in gastric and colon cancer patient. Eur J Gastroenterol 2003; 15:75-80.

23. Ivankovic M, Cukusic A, Gotic I. Telomerase activity in HeLa cervical carcinoma cell line proliferation. Biogerontology 2007;8:163-72.

24. Nasiri M, Zhargami N, Koshki KN, et al. Curcumin silibinin inhibit telomerase expression in T47D human breast cancer cells. Asian Pasific J Cancer Prev 2013;14:3449-53.

25. Zisuh AV, Han TQ. Expression of telomerase and its significance in the diagnosis of pancreatic cancer. Indian J Med Res 2012;135:26-30. 